\title{
Cell Rescue by Nanosequestration: Reduced Cytotoxicity of An Environmental Remediation Residue, $\mathrm{Mg}(\mathrm{OH})_{2}$ Nanoflake/Cr(VI) Adduct
}

\author{
Ruinan Zhang, ${ }^{\dagger}$ Xiaohong Pan, ${ }^{\ddagger}$ Fei Li, ${ }^{\dagger}$ Lin Zhang, ${ }^{\ddagger}$ Shumei Zhai, ${ }^{\dagger}$ Qingxin $\mathrm{Mu}^{\dagger}{ }^{\dagger}$ Jingfu Liu, ${ }^{\S}$ \\ Guangbo Qu, ${ }^{\$}$ Guibin Jiang, ${ }^{\S}$ and Bing Yan*, \\ ${ }^{\dagger}$ School of Chemistry and Chemical Engineering, Shandong University, Jinan 250100, China \\ ${ }^{\ddagger}$ State Key Lab of Structural Chemistry, Fujian Institute of Research on the Structure of Matter, Chinese Academy of Sciences, \\ Fuzhou, Fujian 350002, China \\ ${ }^{\S}$ Research Center for Eco-Environmental Sciences, Chinese Academy of Sciences, Beijing 100085, China
}

\section{Supporting Information}

ABSTRACT: Some nanomaterials, such as $\mathrm{Mg}(\mathrm{OH})_{2}$ nanoflakes, are heavily used in pollutant adsorption and removal. Residues from these environmental remediations are potential hazardous materials. Safety evaluations of these materials are needed for environmental protection and human health. Although nanotoxicity has been widely investigated in recent years, research on the toxicity of nanoparticle/ pollutant adducts has been rather inadequate. Here, we report the cellular perturbations and cytotoxicity of nano- $\mathrm{Mg}(\mathrm{OH})_{2} / \mathrm{Cr}(\mathrm{VI})$ adducts as a case study to elucidate how nanoparticle/pollutant adducts impact human cells. We found that $\mathrm{Mg}(\mathrm{OH})_{2}$ nanoflakes barely enter cells, while desorbed $\mathrm{Cr}(\mathrm{VI})$ anions enter cells, generate ROS, induce cell apoptosis, and cause cytotoxicity. This cytotoxicity is only a fraction of the cytotoxicity of free $\mathrm{Cr}(\mathrm{VI})$ because nano- $\mathrm{Mg}(\mathrm{OH})_{2}$ particles are able to retain more than half of their $\mathrm{Cr}(\mathrm{VI})$ anions.

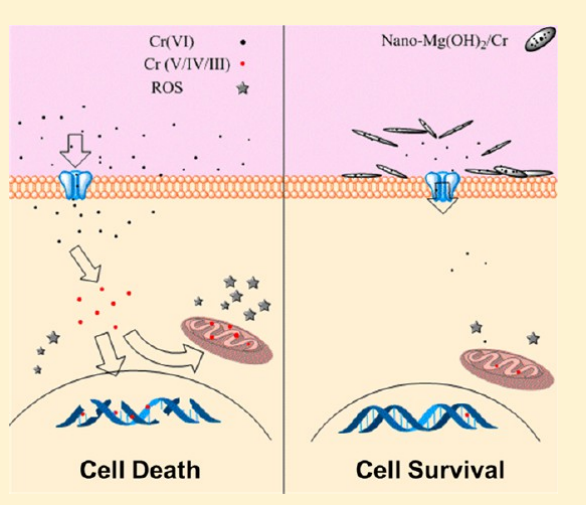

\section{INTRODUCTION}

Air-borne or solution-suspended nanoparticles are health issues because of their toxicity and because of the toxic agents they carry. ${ }^{1,2}$ Nanoparticles have a large specific surface area. To maintain their stability, they tend to adsorb chemical or biological agents on their surfaces to reduce their surface energy. These adsorbents are likely toxic, carcinogenic, viral, or infectious substances. When these particles enter the human body, they pose considerable threats to human health. In addition to these incidental nanoparticle/pollutant adducts, millions of tons of such adducts are formed during environmental remediation, as nanotechnology is increasingly being applied in environmental engineering. 3,4

Chromium has been widely used in industry. ${ }^{5}$ The worldwide environmental release of chromium-containing waste is over 40.8 million tons annually. ${ }^{6}$ Chromium(VI) has been designated as a class 1 carcinogen. $^{7-9}$ Chromium waste is generally landfilled after chemical reduction. However, $\mathrm{Cr}$ (III) is easily oxidized back to $\mathrm{Cr}(\mathrm{VI})$ in the environment. ${ }^{10}$ Furthermore, chromium-containing wastes are readily translocated through the air, water, and soil and endanger the entire ecosystem. ${ }^{11}$ The removal of highly toxic $\mathrm{Cr}(\mathrm{VI})$ from industrial waste is very important. Several approaches, including electrochemical reduction, ${ }^{12}$ ion-exchange, ${ }^{13,14}$ and biological remediation, ${ }^{15}$ have been developed for $\mathrm{Cr}(\mathrm{VI})$ removal from wastewater. With their small size, large surface area, and high surface-absorptivity, nanomaterials have been increasingly used as adsorbents for pollutant removal. ${ }^{16}$ Nanoflakes or diskshaped nanoparticles normally have a reduced internalization $^{17,18}$ and are particularly meaningful for environmental remediation. Specifically, due to their low toxicity and lower cost, magnesium hydroxide nanoflakes (nano- $\mathrm{Mg}(\mathrm{OH})_{2}$ ) have been widely used in pollutant remediation, e.g., the removal of organic pollutants and heavy metal ions such as carcinogenic Cr(VI).,19 This operation, however, creates a new class of species: nanoparticle/pollutant adducts. The annual generation of nano- $\mathrm{Mg}(\mathrm{OH})_{2} / \mathrm{Cr}(\mathrm{VI})$ by Chinese chloralkali and chlorate plants has reached 800000 tons. $^{20,21}$

The adsorption of pollutants to nanoparticles alters the properties of both the pollutant and the nanoparticle. Therefore, the toxicity of these adducts to human and living systems may be quite different from that of the pollutant or nanoparticle alone. For example, the adsorption of natural organic matter to multiwalled carbon nanotubes increases the aqueous stability of hydrophobic nanotubes and toxicity of the adducts to daphnia. ${ }^{22}$ The tributyltin/nano- $\mathrm{TiO}_{2}$ adduct is more toxic to abalone embryos than tributyltin alone. ${ }^{23}$ Similar

Received: November 8, 2013

Revised: December 24, 2013

Accepted: January 6, 2014

Published: January 6, 2014 
synergistic toxicities to aquatic organisms have also been found for $\mathrm{As}, \mathrm{Pb}, \mathrm{Cu}$, and $\mathrm{Cd}$ in the presence of nano- $\mathrm{Al}_{2} \mathrm{O}_{3}$, nano$\mathrm{Fe}_{2} \mathrm{O}_{3}$, and nano- $\mathrm{TiO}_{2}{ }^{24-28}$ Recently, we have observed significant research efforts exerted toward the investigation of nanoparticle toxicity. However, very little attention has been paid to nanoparticle/pollutant adducts. In reality, bare nanoparticles are nonexistent. Nanoparticles always exist as adducts with molecules from the immediate microenvironment. Therefore, investigating the health impacts of such nanoparticle adducts is imperative.

In this investigation, we evaluated the effects of nano$\mathrm{Mg}(\mathrm{OH})_{2}$ and nano- $\mathrm{Mg}(\mathrm{OH})_{2} / \mathrm{Cr}(\mathrm{VI})$ adducts on human cells by assessing their cellular uptake, oxidative stress induction, cell viability, and apoptosis. Because $\mathrm{Cr}(\mathrm{VI})$ is known to induce nephrotoxicity ${ }^{9}$ and hepatic failure, ${ }^{5-9}$ we selected the human hepatocellular carcinoma epithelial cell line HepG2 and embryonic kidney epithelial cell line HEK293 for our investigations. Our results demonstrate that $\mathrm{Mg}(\mathrm{OH})_{2}$ nanoflakes are not evidently internalized by cells and are not cytotoxic. However, $\mathrm{Cr}$ (VI) anions released from nanoadducts are able to enter cells through nonspecific anion channels and cause cell damage. In this case, nano- $\mathrm{Mg}(\mathrm{OH})_{2} / \mathrm{Cr}(\mathrm{VI})$ adduct formation significantly reduces the cellular uptake of $\mathrm{Cr}(\mathrm{VI})$ anions and its associated cytotoxicity.

\section{MATERIALS AND METHODS}

Nano-Mg(OH) ${ }_{2}$ and Nano-Mg(OH) $)_{2} / \mathrm{Cr}(\mathrm{VI}) \cdot \operatorname{Mg}(\mathrm{OH})_{2}$ nanoflakes were synthesized by coprecipitation of magnesium chloride hexahydrate and sodium hydroxide as described before. $^{29} \mathrm{Nano}-\mathrm{Mg}(\mathrm{OH})_{2} / \mathrm{Cr}(\mathrm{VI})$ was prepared by stirring nano- $\mathrm{Mg}(\mathrm{OH})_{2}$ in a $\mathrm{K}_{2} \mathrm{Cr}_{2} \mathrm{O}_{7}$ solution $(80 \mathrm{mg} / \mathrm{L})$ for $4 \mathrm{~h}$. The suspension was then washed and centrifuged at $5000 \mathrm{~g} 3$ times.

Characterization of Nano- $\mathrm{Mg}(\mathrm{OH})_{2}$ and Nano-Mg$(\mathrm{OH})_{2} / \mathrm{Cr}(\mathrm{VI})$. The morphology and size of the nanoparticles were analyzed using a transmission electron microscope (TEM, JEM-1011, JEOL, Japan). Their hydrodynamic size was analyzed using a dynamic light scattering instrument (DLS, Nano ZS 90, Malvern, UK). Samples were prepared in water or Dulbecco's modified eagle medium (DMEM). Samples were sonicated before DLS determination. The thickness of the nanoflakes was measured using an atomic force microscope (AFM, NanoScope IIIA, Veeco Instruments Inc., United States). Images were obtained in the tapping mode and then analyzed using the accompanying Veeco Nanoscope software. Crystal structures of the sample powders were also analyzed by X-ray diffraction (XRD) using a PANalytical X'Pert PRO diffractometer with $\mathrm{Cu} \mathrm{K} \alpha$ radiation. Data were collected with continuous scanning $2 \theta$ from $5^{\circ}$ to $85^{\circ}$ at $0.017^{\circ}$ per step. To understand the surface charge properties of the nanoflakes, the zeta potentials of the suspensions were analyzed using a Zeta Sizer instrument (Nano ZS 90, Malvern, UK). The adsorption capacity of nano- $\mathrm{Mg}(\mathrm{OH})_{2}$ for $\mathrm{Cr}(\mathrm{VI})$ was determined by ICPAES (Optima7000DV, PerkinElmer, Inc., United States). A sample of supernatant or nano- $\mathrm{Mg}(\mathrm{OH})_{2} / \mathrm{Cr}(\mathrm{VI})$ adducts was dissolved in $\mathrm{HNO}_{3}$ and then diluted with double distilled water (DDW) (18.2 M $\Omega$, Pall, Reservoir, United States). The dissolved or the adsorbed amount of $\mathrm{Cr}(\mathrm{VI})$ was calculated from the content of $\mathrm{Cr}$ as obtained from ICP-AES elemental analysis. Data were from the average of three independent measurements.

Cell Culture. The human hepatocellular carcinoma epithelial cell line HepG2 (ATCC) and embryonic kidney epithelial cell line HEK293 (ATCC) were cultured in
Dulbecco's Modified Eagle's Medium (GIBCO, Life Technologies, United States) with $10 \%$ fetal bovine serum (HyClone, Thermo Fisher Scientific Inc., United States), 100 $\mathrm{U} / \mathrm{mL}$ penicillin, and $100 \mu \mathrm{g} / \mathrm{mL}$ streptomycin solution (HyClone, Thermo Fisher Scientific Inc., United States) at $37{ }^{\circ} \mathrm{C}$ in a $5 \% \mathrm{CO}_{2}$ incubator.

Cellular Uptake. Cells were incubated with $200 \mu \mathrm{g} / \mathrm{mL}$ nano- $\mathrm{Mg}(\mathrm{OH})_{2}$ or $206.2 \mu \mathrm{g} / \mathrm{mL}$ nano- $\mathrm{Mg}(\mathrm{OH})_{2} / \mathrm{Cr}(\mathrm{VI})$ for 2 $\mathrm{h}$. After washing, cell pellets were fixed for $1 \mathrm{~h}$ in $2 \%$ osmium tetroxide with $3 \%$ potassium ferricyanide. Thin $(70 \mathrm{~nm})$ sections were cut on a Leica UC6 ultramicrotome for TEM observation. Quantification of cellular uptake was performed by ICP-MS analysis after incubation with nanoparticles. The cells were washed, sonicated, and digested overnight in Aqua Regia at $37{ }^{\circ} \mathrm{C}$. The cellular uptake of $\mathrm{Mg}$ and $\mathrm{Cr}$ was determined by ICP-MS (Agilent 7500 series, Agilent Technologies, United States), and a series of $\mathrm{Mg} / \mathrm{Cr}$ standard solutions $(0,5,10,20$, 50,100 , and $200 \mu \mathrm{g} / \mathrm{mL}$ ) with ${ }^{236} \mathrm{Y}$ as an internal standard for calibration. To quantify the cellular uptake of free $\mathrm{Cr}(\mathrm{VI})$, the anion exchanger inhibitor 4,4'-diisothiocyano-2,2' -stilbenedisulfonic acid (DIDS) (Sigma Corporation of America) was used to block free $\mathrm{Cr}(\mathrm{VI})\left(\mathrm{Cr}_{2} \mathrm{O}_{7}{ }^{2-}\right)$ permeation. A nontoxic inhibition concentration of DIDS $(0.1 \mathrm{mM})$ was selected using the WST-1 assay (Supporting Information Figure 2). Cells were preincubated with $0.1 \mathrm{mM}$ DIDS for $30 \mathrm{~min}$, and cell uptake experiments were carried out as described.

Cell Viability. Cells (5000 cells/well) were seeded into a 96-well plate $24 \mathrm{~h}$ before incubation with nanoparticles, adducts, and $\mathrm{Cr}(\mathrm{VI})$ for 24 or $48 \mathrm{~h}$. The exposure concentrations of nano- $\mathrm{Mg}(\mathrm{OH})_{2}$ were 25,100 , and $400 \mu \mathrm{g} /$ $\mathrm{mL}$. According to the determined adsorption capacity of $\mathrm{Cr}(\mathrm{VI})$ on $\mathrm{Mg}(\mathrm{OH})_{2}$, the concentrations of adducts were 25.8 , 103.1 , and $412.4 \mu \mathrm{g} / \mathrm{mL}$, while concentrations of $\mathrm{Cr}(\mathrm{VI})$ were $0.8,3.1$, and $12.4 \mu \mathrm{g} / \mathrm{mL}$. Cell mitochondria dehydrogenase activity, which is proportional to cell viability, was determined using the WST-1 assay (Beyotime Institute of Biotechnology, China). Cell morphology after being treated with $100 \mu \mathrm{g} / \mathrm{mL}$ of nano- $\mathrm{Mg}(\mathrm{OH})_{2}$, the corresponding adducts, and $\mathrm{Cr}(\mathrm{VI})$ were also monitered using an optical microscope (Olympus IX71, Olympus Corporation, Japan).

Reactive Oxygen Species (ROS) Generation and Cell Apoptosis. The production of cellular ROS was determined by flow cytometry (Guava Millipore, Merck KGaA, Germany) using dichlorofluorescein diacetate as a fluorescent marker. The mean fluorescence intensity of a given amount of cells was obtained using GuavaSoft, which is the analysis software for Guava Millipore Flow Cytometer by BD Biosciences (San Jose, California, U.S.A.). Cells given the same treatments were also washed, trypsinized, and resuspended in PBS for apoptosis analysis. The Nexin-V reagent (Guava, Millipore, Merck KGaA, Germany) was used for cell staining, followed by flow cytometry analysis.

\section{RESULTS AND DISCUSSION}

Nanoparticle/pollutant adducts constitute a newly emerging environmental hazard. To evaluate their cytotoxicity, a careful characterization of nanoparticles and their adducts as well as their solubilization, desorption behavior, and aggregation tendency is crucial.

Properties of Nano-Mg(OH) $)_{2}$ and Nano-Mg(OH $)_{2} /$ $\mathrm{Cr}(\mathrm{VI})$ Systems. The morphology, size distribution, aqueous dispersity, crystal structure, and adsorption capacity of nano$\mathrm{Mg}(\mathrm{OH})_{2}$ and nano- $\mathrm{Mg}(\mathrm{OH})_{2} / \mathrm{Cr}(\mathrm{VI})$ were characterized 

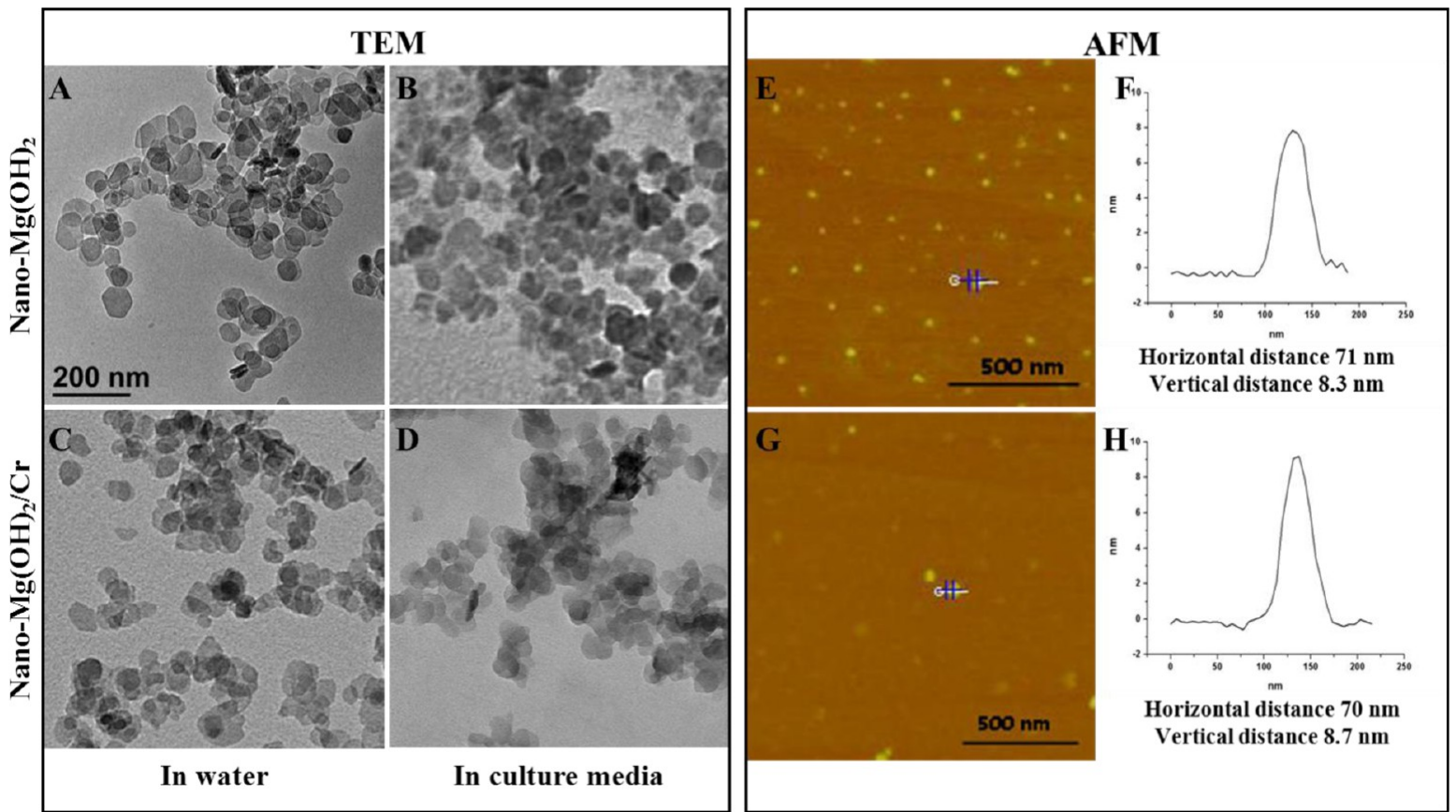

Figure 1. Characterization of nano- $\mathrm{Mg}(\mathrm{OH})_{2}$ and nano- $\mathrm{Mg}(\mathrm{OH})_{2} / \mathrm{Cr}(\mathrm{VI})$ adducts by TEM and AFM. The scale bar in A is for all TEM panels.

Table 1. Characterization of $\mathrm{Nano}-\mathrm{Mg}(\mathrm{OH})_{2}$ and $\mathrm{Nano}-\mathrm{Mg}(\mathrm{OH})_{2} / \mathrm{Cr}(\mathrm{VI})^{a}$

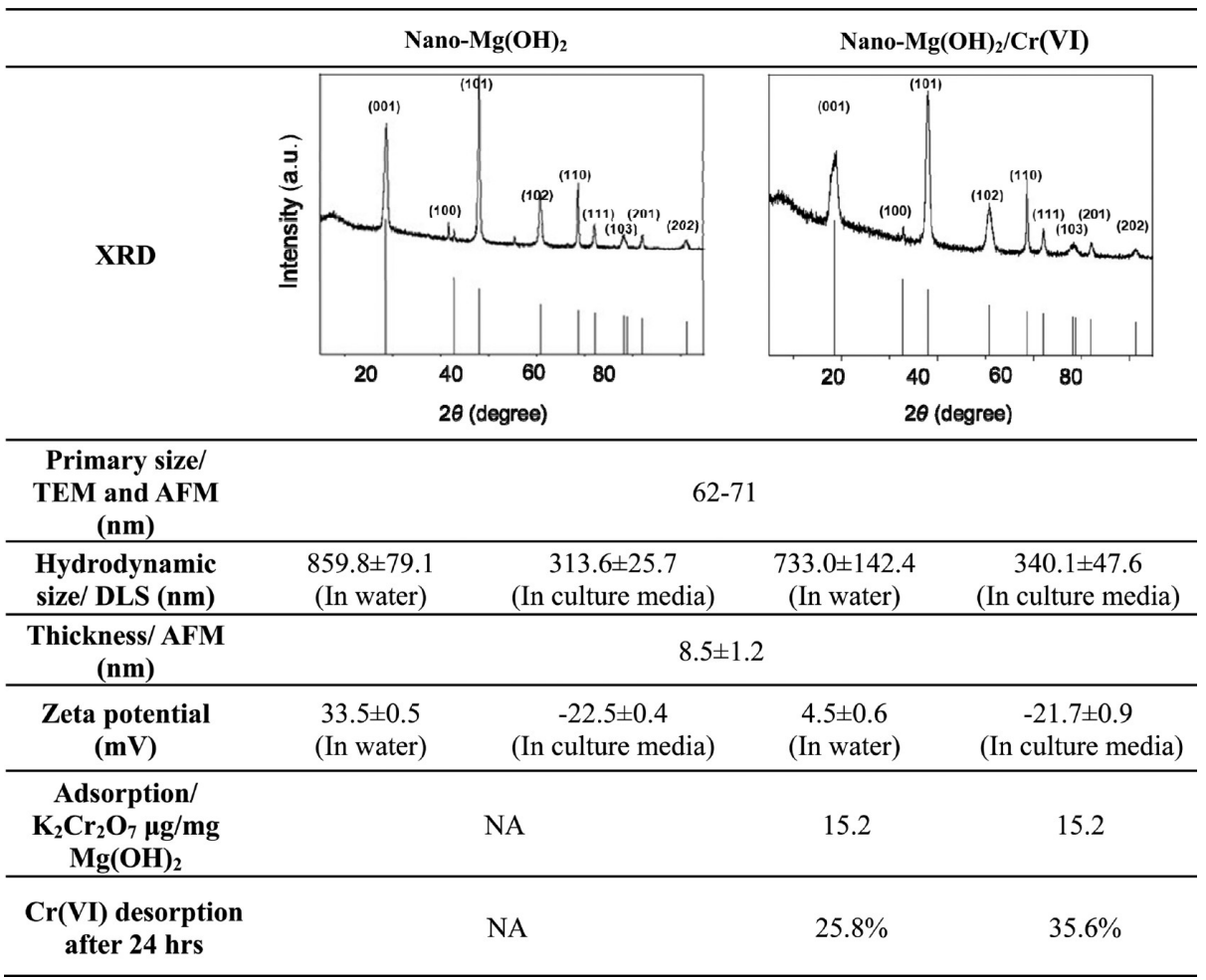

aAFM, XRD, and TEM diameter and thickness (AFM) are not related to "water" or "culture medium". They can be listed at the top of table. The rest are listed below those four properties and only at the top list "in water" and "in culture medium", not at every item.

(Figure 1 and Table 1). TEM (Figure 1) showed hexagonal shape of nano- $\left(\mathrm{Mg}(\mathrm{OH})_{2}\right.$ and the adducts with a diameter of $\sim 70 \mathrm{~nm}$. AFM (Figure 1) showed that the thickness of these nanoflakes was about 8-9 $\mathrm{nm}$. The XRD pattern of nano$\mathrm{Mg}(\mathrm{OH})_{2}$ particles (Table 1) also reveals that diffraction peaks can be well-indexed as hexagonal nanoflakes with a calculated crystallite size of $10.2 \pm 0.4 \mathrm{~nm}$ in the [001] direction using the
Scherrer equation. This value was very close to the value of 8-9 nm measured by AFM. The hydrodynamic diameter of the nanoflakes in water was $700-800 \mathrm{~nm}$ as determined by dynamic light scattering The increased size was most likely due to the formation of a hydration shell around the nanoflakes, their disk-like shape, and partial aggregation of the nanoflakes. $^{30,31}$ Because the nanoparticles were suspended in cell 
A
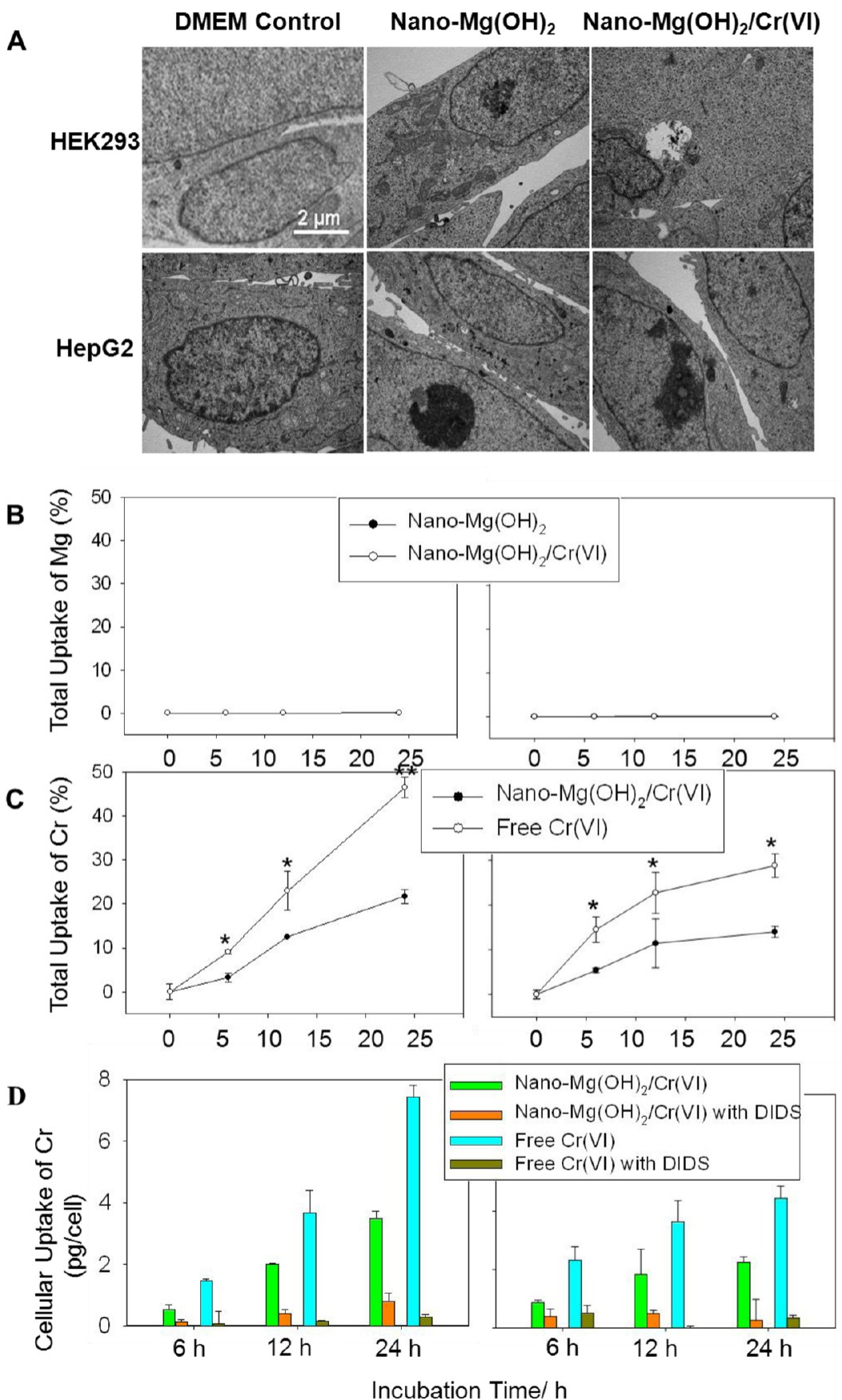

Figure 2. Cellular uptake of nano- $\mathrm{Mg}(\mathrm{OH})_{2}$ and nano- $\mathrm{Mg}(\mathrm{OH})_{2} / \mathrm{Cr}(\mathrm{VI})$. (A) TEM observation of cells treated with nanoflakes $(100 \mu \mathrm{g} / \mathrm{mL})$ for $24 \mathrm{~h}$. (B and C) Quantitative determination of the internalized $\mathrm{Mg}$ and $\mathrm{Cr}(\mathrm{VI})$ by ICP-MS. Total uptake\% $=$ The internalized $\mathrm{Mg}^{27} /$ total dosed $\mathrm{Mg}^{27} \times 100 \%$. All the uptake data were normalized to the cell numbers. (D) Cell uptake after the anion channels are blocked. In B-D, left panels are for HEK293 and right panels are for HepG2. $(0.01<* p$ value $<0.05,0.001<* * p$ value $<0.01)$. The scale bar in A is for all TEM panels.

culture medium for the cell-based assays, we also analyzed their hydrodynamic diameter in this medium. Protein adsorption on nanoparticles' surface ${ }^{32,33}$ can break large aggregates of particles into smaller aggregates because protein coatings effectively reduce the surface energy of nanoparticles. We observed that serum proteins facilitated nanoparticle dispersion and reduced their hydrodynamic size to $\sim 300 \mathrm{~nm}$. Protein adsorption should increase the size of each individual particle. ${ }^{33,34}$ Yet, the average dynamic size of the nanoflakes was reduced from 800 to $300 \mathrm{~nm}$, suggesting that protein binding actually broke up most of the aggregates. The zeta-potential value of nano$\mathrm{Mg}(\mathrm{OH})_{2}$ was approximately $+30 \mathrm{mV}$ in water. The positive charge of the nanoflakes promoted the adsorption of $\mathrm{Cr}(\mathrm{VI})$ anions. After adsorption, the zeta potential of adducts became negative $(-22 \mathrm{mV})$. According to the electric double layer diffusion theory, zeta potential primarily depends on the charge difference of the positive colloidal nucleus and the surrounding negative ions. The $\mathrm{Cr}_{2} \mathrm{O}_{7}{ }^{2-}$ anions neutralized the colloidal nucleus and reduced the positive potential of the whole colloidal particles. The diffraction peaks for adducts in the XRD spectra matched the hexagonal crystal and the dimension of nano- $\mathrm{Mg}(\mathrm{OH})_{2}$. Therefore, the $\mathrm{Cr}(\mathrm{VI})$ adsorption did not change the crystal lattice of nano- $\mathrm{Mg}(\mathrm{OH})_{2}$. This demonstrated that the chemical nature of the nano- $\mathrm{Mg}(\mathrm{OH})_{2}$ crystal and 


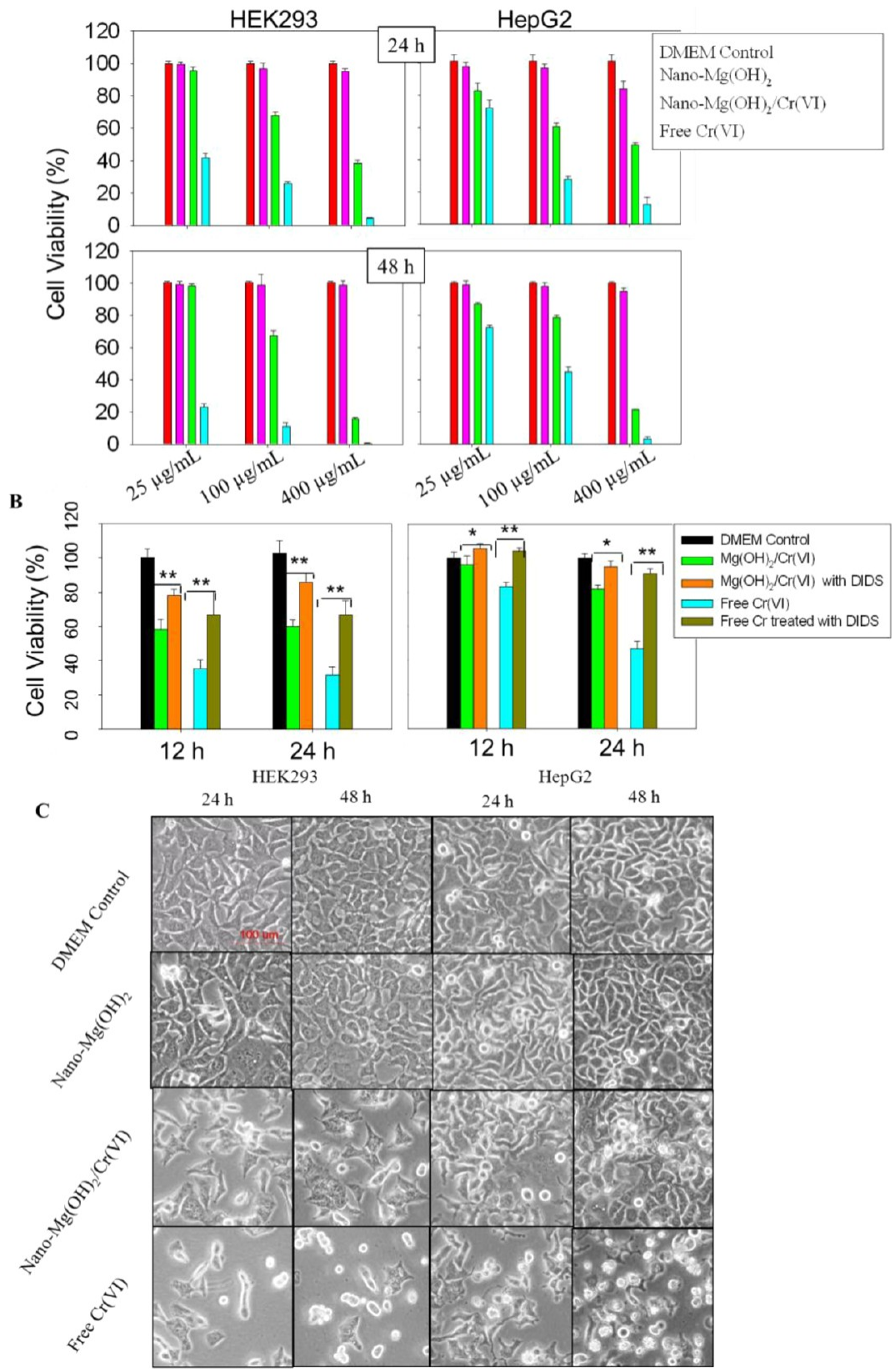

Figure 3. Cytotoxicity of nano- $\mathrm{Mg}(\mathrm{OH})_{2}$ and nano- $\mathrm{Mg}(\mathrm{OH})_{2} / \mathrm{Cr}(\mathrm{VI})$. (A) Cell viability assessment by quantifying mitochondria dehydrogenase activity. (B) Cytotoxicity after blocking anion channels. (C) Morphology of treated cells at $24 \mathrm{~h}$ (equivalent to $10.5 \mu \mathrm{M} \mathrm{Cr}(\mathrm{VI})$ ).

$\mathrm{Cr}(\mathrm{VI})$ anions were not altered and that $\mathrm{Cr}(\mathrm{VI})$ anions were only physically adsorbed onto the surface of the nanoflakes. The adsorption of $\mathrm{Cr}(\mathrm{VI})$ or $\mathrm{Cr}_{2} \mathrm{O}_{7}^{2-}$ reduced the positive surface charge of nano- $\mathrm{Mg}(\mathrm{OH})_{2}$ slightly in water but did not change the size, surface charge, or aqueous dispersion properties of nano- $\mathrm{Mg}(\mathrm{OH})_{2}$ in cell culture medium. This was likely due to serum proteins heavily bound to nanoparticles $^{32,33}$ and dominated the modification on surface electrical properties.

Because $\mathrm{Cr}(\mathrm{VI})$ anions are only physically adsorbed onto nano- $\mathrm{Mg}(\mathrm{OH})_{2}$, an adsorption/desorption equilibrium must occur in solution. By quantitatively determining the amount of $\mathrm{Cr}$ (VI) by ICP-MS, the adsorption capacity of the nanoflakes was found to be $15.2 \mathrm{mg} \mathrm{K}_{2} \mathrm{Cr}_{2} \mathrm{O}_{7} / \mathrm{g}$ nano- $\mathrm{Mg}(\mathrm{OH})_{2}$. This value was used to determine the concentration of the control $\mathrm{Cr}(\mathrm{VI})$ in the cell-based assays. By using HEPES buffer solution in cell culture media, the $\mathrm{pH}$ was maintained at 7.0. The balance of the adsorption/desorption equilibrium indicated that, in the nano- $\mathrm{Mg}(\mathrm{OH})_{2} / \mathrm{Cr}(\mathrm{VI})$ system, $\mathrm{Cr}(\mathrm{VI})$ anions existed as free and adsorbed forms. In a simulated adsorption/ desorption experiment, approximately $25-35 \%$ of the $\mathrm{Cr}(\mathrm{VI})$ anions were in free-anion form after incubation for $24 \mathrm{~h}$ in water and cell culture medium (Supporting Information, Figure S1).

Adsorption to Nano-Mg(OH) 2 Outside of Cells Reduced the Cellular Uptake of $\mathrm{Cr}(\mathrm{VI})$ Anions. Twodimensional polymeric nanodisks mostly bound to cell surfaces with little internalization. ${ }^{18} \mathrm{Nano}-\mathrm{Mg}(\mathrm{OH})_{2}$ nanoflakes were rarely detected inside $E$. coli and primarily bound to the bacterial surface. ${ }^{29}$ Because of the repellent interaction between electronegative cell membranes, negatively charged nanoparticles are internalized less than positively charged nano- 
particles. ${ }^{35-38} \mathrm{Mg}(\mathrm{OH})_{2}$ nanoflakes were nearly two-dimensional nanoparticles and were negatively charged after $\mathrm{Cr}(\mathrm{VI})$ adsorption. On the basis of these considerations, we hypothesized that nano- $\mathrm{Mg}(\mathrm{OH})_{2}$ nanoflakes might not be internalized well. As a result, the cell uptake and cytotoxicity of $\mathrm{Cr}(\mathrm{VI})$ anions might be reduced. To test this hypothesis, we first investigated the cellular uptake of nano- $\mathrm{Mg}(\mathrm{OH})_{2}$ and its $\mathrm{Cr}$ (VI) adducts by TEM and ICP-MS. The nanoflakes were rarely observed inside cells after incubation for $24 \mathrm{~h}$ (Figure 2A). Consistent with the TEM observations, cellular $\mathrm{Mg}$ was less than $0.7 \mathrm{pg} /$ cell (Supporting Information, Figure S2A) or $0.2 \%$ of the total applied nano- $\mathrm{Mg}(\mathrm{OH})_{2}$ dose, as determined by ICP-MS (Figure 2B). Cr(VI) adsorption did not increase the cellular uptake of $\mathrm{Mg}(\mathrm{OH})_{2}$ nanoflakes. These findings indicated that the cellular uptake of $\mathrm{Cr}(\mathrm{VI})$ through nano$\mathrm{Mg}(\mathrm{OH})_{2}$ carriers was rare.

Because the adsorbed $\mathrm{Cr}(\mathrm{VI})$ anions might be desorbed from nanoparticles and free $\mathrm{Cr}(\mathrm{VI})$ anions might enter a cell through nonspecific anion channels in the cell membrane, we then analyzed the cellular uptake of free $\mathrm{Cr}(\mathrm{VI})$ (Figure 2C). The uptake rates of $\mathrm{K}_{2} \mathrm{Cr}_{2} \mathrm{O}_{7}$ in HEK293 and HepG2 cells were determined to be $7.69 \times 10^{-5}$ and $1.22 \times 10^{-4} \mathrm{pmol} / \mathrm{min} \cdot \mathrm{cell}$, respectively. Free $\mathrm{Cr}(\mathrm{VI})$ anions are known to enter cells through anion channels with an uptake rate of $5.15 \times 10^{-4}$ $\mathrm{pmol} / \mathrm{min} \cdot$ cell after treatment with $20 \mathrm{mM} \mathrm{Cr}(\mathrm{VI}) .^{39,40}$ The cellular uptake of $\mathrm{Cr}$ in the nano- $\mathrm{Mg}(\mathrm{OH})_{2} / \mathrm{Cr}(\mathrm{VI})$ group was significantly reduced compared to free $\mathrm{Cr}(\mathrm{VI})$ at all time points (Figure 2C). After a 24-h incubation, the intracellular Cr uptake of the nano- $\mathrm{Mg}(\mathrm{OH})_{2} / \mathrm{Cr}(\mathrm{VI})$ group was approximately $45 \%$ of free $\mathrm{Cr}(\mathrm{VI})$ in HEK293 and 50\% of that in HepG2 cells. Because nano- $\mathrm{Mg}(\mathrm{OH})_{2}$ rarely enter cells, $\mathrm{Cr}(\mathrm{VI})$ anions must have entered the cells after they were desorbed from the nanoflakes. Incubation of nano- $\mathrm{Mg}(\mathrm{OH}) 2 / \mathrm{Cr}(\mathrm{VI})$ adducts with cell culture medium for $24 \mathrm{~h}$ released $35 \%$ of $\mathrm{Cr}(\mathrm{VI})$ anions. This value was slightly different from the cellular uptake of $\mathrm{Cr}(45-50 \%)$ compared to free $\mathrm{Cr}(\mathrm{VI})$, likely due to enhanced $\mathrm{Cr}(\mathrm{VI})$ release when a portion of the extracellular $\mathrm{Cr}(\mathrm{VI})$ anions were internalized.

$\mathrm{Cr}(\mathrm{VI})$ anions readily penetrate plasma membranes through the nonspecific anion exchange carrier "band-3" proteins. ${ }^{41}$ To determine whether $\mathrm{Cr}(\mathrm{VI})$ entered cells through these channels, we used the anion channel blocker 4,4'-diisothiocyano-2,2'-stilbenedisulfonic acid (DIDS) to block free $\mathrm{Cr}(\mathrm{VI})$ permeation through channels. DIDS covalently binds to "band3 " proteins and blocks over $80 \%$ of the anion channels in live cells. ${ }^{42}$ We determined the $\mathrm{Cr}(\mathrm{VI})$ uptake in the presence and absence of nano- $\mathrm{Mg}(\mathrm{OH})_{2}$ before and after the anion channels were blocked (Figure 2D). Cellular uptake of free $\mathrm{Cr}(\mathrm{VI})$ anions was almost completely blocked by the channel inhibitor. Furthermore, uptake of $\mathrm{Cr}(\mathrm{VI})$ from nano- $\mathrm{Mg}(\mathrm{OH})_{2} / \mathrm{Cr}(\mathrm{VI})$ was also significantly blocked (Figure 2D), demonstrating that $\mathrm{Cr}(\mathrm{VI})$ anions entered cells through anion channels after they were desorbed.

The interactions between nanoparticle/toxicant adducts and cells are complex. Adducts can enter cells and cause synergistic toxicity, while desorbed toxicants can also enter cells and generate further cellular damage. In the case of the nano$\mathrm{Mg}(\mathrm{OH})_{2} / \mathrm{Cr}(\mathrm{VI})$ adduct, the situation is simplified because nanoflakes do not enter cells. The only possibility is that desorbed $\mathrm{Cr}(\mathrm{VI})$ enters cells and causes cytotoxicity, and the above-mentioned results demonstrating the blocking of $\mathrm{Cr}(\mathrm{VI})$ internalization by channel blockers support this hypothesis.
Adsorption to Nano-Mg(OH $)_{2}$ Reduces the Cytotoxicity of $\mathrm{Cr}(\mathrm{VI})$. Because nano- $\mathrm{Mg}(\mathrm{OH})_{2}$ did not enter cells, the cytotoxicity of nano- $\mathrm{Mg}(\mathrm{OH})_{2} / \mathrm{Cr}(\mathrm{VI})$ might be attributable to free $\mathrm{Cr}(\mathrm{VI})$ anions. Adsorption of $\mathrm{Cr}(\mathrm{VI})$ to nano- $\mathrm{Mg}(\mathrm{OH})_{2}$ reduced the amount of $\mathrm{Cr}(\mathrm{VI})$ that was readily taken up by cells. We therefore expected that nano- $\mathrm{Mg}(\mathrm{OH})_{2} / \mathrm{Cr}(\mathrm{VI})$ might lead to less cytotoxicity when compared to free $\mathrm{Cr}(\mathrm{VI})$. To test this, we determined the viability of cells by analyzing the activity of mitochondria dehydrogenase, which is proportional to the number of live cells. Cells treated with nano$\mathrm{Mg}(\mathrm{OH})_{2} / \mathrm{Cr}(\mathrm{VI})$ and $\mathrm{K}_{2} \mathrm{Cr}_{2} \mathrm{O}_{7}$ exhibited time- and dosedependent cell growth inhibition (Figure 3A). To corroborate this finding, microscopic images showed cell shrinkage, round shapes, and the loss of attachment after treatment with nano$\mathrm{Mg}(\mathrm{OH})_{2} / \mathrm{Cr}(\mathrm{VI})$ or $\mathrm{Cr}(\mathrm{VI})$ (Figure 3C). Nano- $\mathrm{Mg}(\mathrm{OH})_{2} /$ $\mathrm{Cr}(\mathrm{VI})$ rescued these cells by increasing cell viability by 2 -fold. Because $\mathrm{Cr}(\mathrm{VI})$ anions were partially desorbed from nanoflakes in cell culture media, we speculated that the cytotoxicity of nano- $\mathrm{Mg}(\mathrm{OH})_{2} / \mathrm{Cr}(\mathrm{VI})$ was mainly caused by free $\mathrm{Cr}(\mathrm{VI})$. We examined this scenario by blocking anion channels using DIDS (Figure 3B). Cell viability was significantly increased when anion channels were blocked. For the HEK293 cell line, cell viability increased to approximately $90 \%$, while HepG2 cells showed nearly $100 \%$ viability. Thus, the cytotoxicity of nano$\mathrm{Mg}(\mathrm{OH})_{2} / \mathrm{Cr}(\mathrm{VI})$ was attributed to free $\mathrm{Cr}(\mathrm{VI})$ anions that were desorbed from nanoflakes. This result was consistent with the above-mentioned cellular uptake results.

Adsorption to Nano- $\mathrm{Mg}(\mathrm{OH})_{2}$ Remediated $\mathrm{Cr}(\mathrm{VI})$ Induced Oxidative Stress and Apoptosis. The mode of action for the carcinogenicity of $\mathrm{Cr}(\mathrm{VI})$ has been proposed before. $^{43} \mathrm{Cr}(\mathrm{VI})$ anions readily diffuse into cells through nonspecific anion channels ${ }^{41}$ and are reduced to the "reactive intermediates" $\mathrm{Cr}(\mathrm{V})$ and $\mathrm{Cr}(\mathrm{III})$ by antioxidative enzymes inside the cells. ${ }^{44,45}$ During this process, molecular oxygen is reduced to superoxide $\left(\mathrm{O}_{2} \bullet^{-}\right), \mathrm{H}_{2} \mathrm{O}_{2}$, and hydroxyl radicals $(\mathrm{OH} \bullet)$ through a Fenton-like reaction. ${ }^{46}$ The generation of oxidative stress causes considerable cell dysfunction, including DNA damage, ${ }^{47,48}$ cell cycle arrest, ${ }^{49}$ and apoptosis. ${ }^{50-52}$ We therefore investigated the induction of oxidative stress and cell apoptosis after various treatments. $\mathrm{Nano}-\mathrm{Mg}(\mathrm{OH})_{2}$ alone did not significantly increase cellular ROS; however, the exposure of both cell lines to $\mathrm{K}_{2} \mathrm{Cr}_{2} \mathrm{O}_{7}$ significantly elevated the cellular ROS levels (Figure 4A), which was consistent with a previous observation in HepG2 cells. ${ }^{8}$ In contrast to free $\mathrm{Cr}(\mathrm{VI})$, the nano- $\mathrm{Mg}(\mathrm{OH})_{2} / \mathrm{Cr}(\mathrm{VI})$ group generated ROS levels that were $40 \%$ of that induced by $\mathrm{Cr}(\mathrm{VI})$ in HEK 293 and $51 \%$ of that by $\mathrm{Cr}(\mathrm{VI})$ in HepG2 cells at $48 \mathrm{~h}$ (Figure 4B).

Although the molecular mechanism of toxicity due to $\mathrm{Cr}(\mathrm{VI})$ has not been completely clarified, the consensus is that $\mathrm{Cr}(\mathrm{VI})$ suppresses cellular receptors that are involved in the immune response and activates cell cycle-related and proapoptosis genes. $^{53}$ The reduction of $\mathrm{Cr}(\mathrm{VI})$ to $\mathrm{Cr}(\mathrm{III})$ induces cellular oxidative stress and leads to cell cycle arrest, apoptosis, and neoplastic transformation. ${ }^{54}$ We found that $\mathrm{Cr}(\mathrm{VI})$ induced significant cell apoptosis, but the adsorption of $\mathrm{Cr}(\mathrm{VI})$ onto nano- $\mathrm{Mg}(\mathrm{OH})_{2}$ reduced the number of apoptotic cells (Figure 4C). The apoptotic cell population was reduced by $40 \%$ in the nano- $\mathrm{Mg}(\mathrm{OH})_{2} / \mathrm{Cr}(\mathrm{VI})$ group when compared to the $\mathrm{Cr}(\mathrm{VI})$ group (Figure $4 \mathrm{C}$ ). Therefore, the presence of $\mathrm{Mg}(\mathrm{OH})_{2}$ nanoflakes reduced the ROS and cell apoptosis induced by $\mathrm{Cr}(\mathrm{VI})$. The above results show that nano- $\mathrm{Mg}(\mathrm{OH})_{2}$ particles are not toxic and that cellular ROS generation and apoptosis induction result from highly toxic $\mathrm{Cr}(\mathrm{VI})$ anions. Because of 

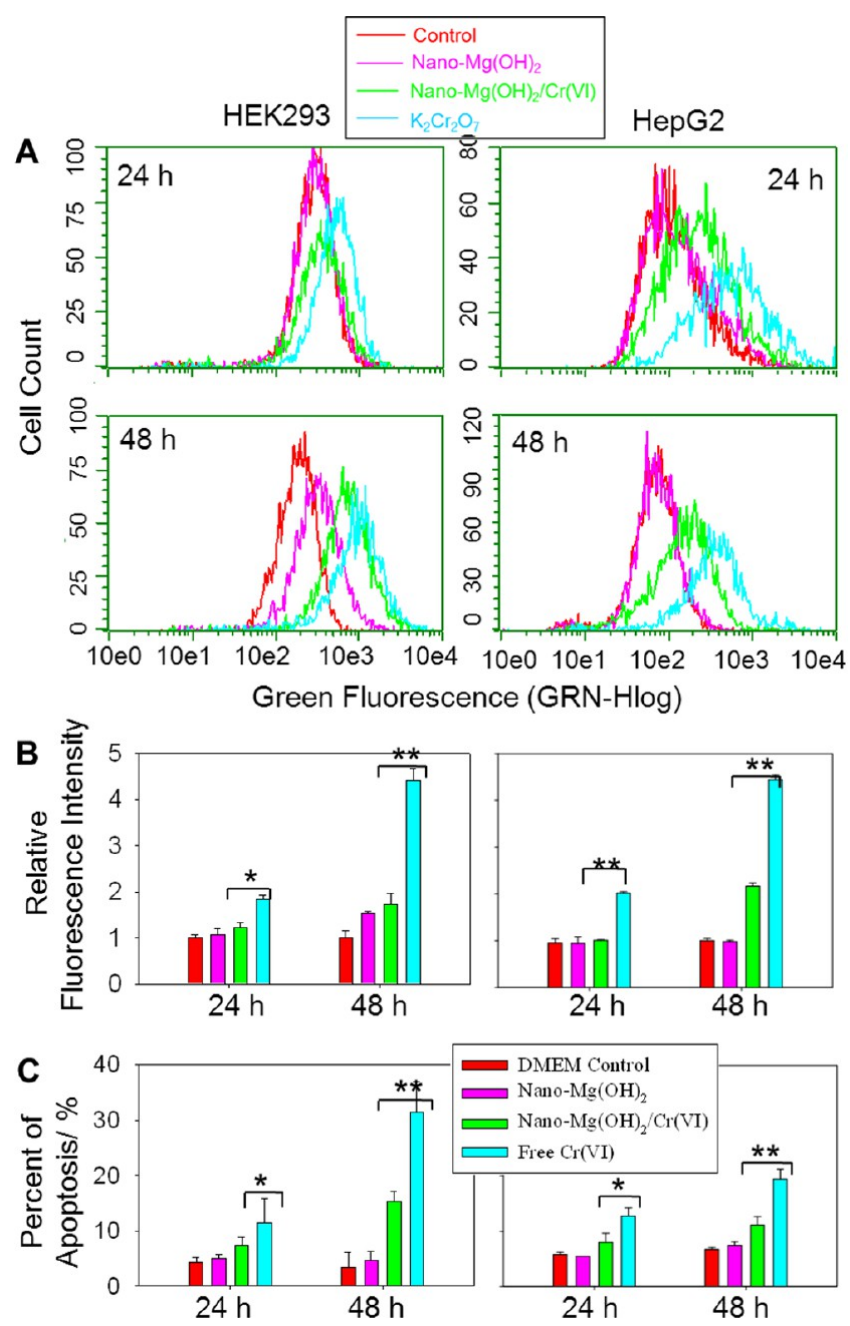

Figure 4. Induction of cellular ROS and cell apoptosis. (A) Determination of ROS level by flow cytometry and (B) quantification of flow cytometry data after normalization. (C) Cell apoptosis analysis by flow cytometry after cells were stained with Guava Nexin $(0.01<$ $* p$ value $<0.05,0.001<* * p$ value $<0.01)$.

the strong adsorption between nano- $\mathrm{Mg}(\mathrm{OH})_{2}$ flakes and $\mathrm{Cr}(\mathrm{VI})$ anions, the adducts exhibit significantly reduced cytotoxicity (Table 2).

Ambient and solubilized nanoparticles always exist as adducts with environmental molecules; however, the adsorbed species are often environmental pollutants. In addition to investigating the toxicity of nanoparticles, understanding the toxicity of nanoparticle/pollutant adducts has become imperative. Nanoparticle/pollutant adducts are normally in equilibrium with adsorbed and desorbed pollutant species. In the case of nano-
$\mathrm{Mg}(\mathrm{OH}) 2 / \mathrm{Cr}(\mathrm{VI})$ adducts (Figure 5), nearly half of the $\mathrm{Cr}(\mathrm{VI})$ anions could be desorbed from nanoparticles. Mg-

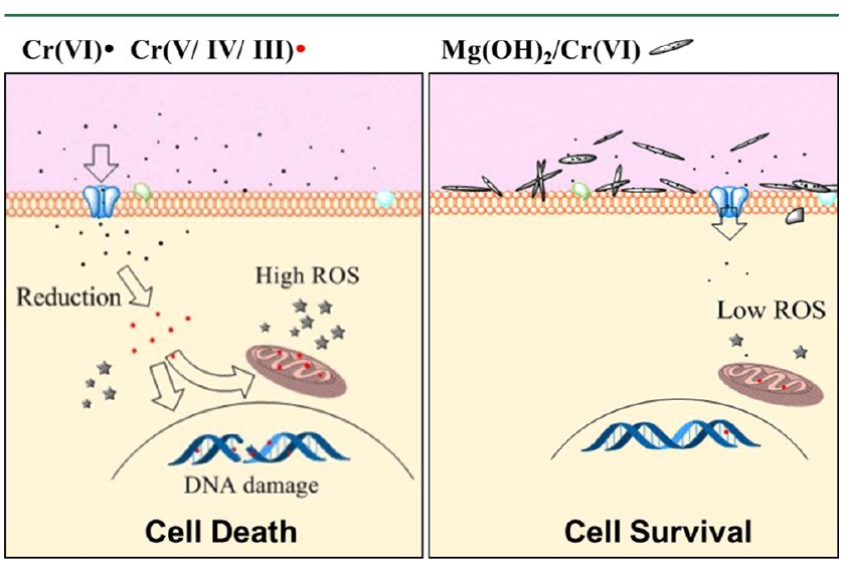

Figure 5. Cartoon illustrations showing interactions of free $\mathrm{Cr}(\mathrm{VI})$ and nano- $\mathrm{Mg}(\mathrm{OH})_{2} / \mathrm{Cr}(\mathrm{VI})$ with cells.

$(\mathrm{OH})_{2}$ nanoflakes do not enter cells, most likely because of their nanoflake shape. However, desorbed $\mathrm{Cr}(\mathrm{VI})$ anions enter cells through nonspecific anion channels. These internalized $\mathrm{Cr}$ (VI) anions increase cellular ROS, induce cell apoptosis, and cause cell death. Because nanoflakes strongly retain about half of their $\mathrm{Cr}(\mathrm{VI})$ anions, the cytotoxicity of the adducts is significantly reduced when compared to $\mathrm{Cr}(\mathrm{VI})$ anions. Our findings have important implications for the environmental use of nanotechnology. Because two-dimensional nanoparticles are not readily to enter cells without significant aggregation, we believe that various nanomaterials that are engineered into twodimensional shape are highly suitable for environmental remediation. Because $\mathrm{Mg}(\mathrm{OH})_{2}$ nanoflakes themselves have little cytotoxicity and have superb adsorption capacity, they will continuously be used in pollutant removal applications. However, although the resulting nanoadducts have significantly reduced cytotoxicity, they are still toxic and need to be wellcontained. It is highly necessary to further process these adducts to eliminate or recover nanomaterials and the desorbed pollutants. ${ }^{4}$

\section{ASSOCIATED CONTENT}

\section{Supporting Information}

Figures S1 and S2. This material is available free of charge via the Internet at http://pubs.acs.org.

\section{AUTHOR INFORMATION}

\section{Corresponding Author}

*Phone: +86 531 88366232. Fax: +86 531 88380029. E-mail: drbingyan@yahoo.com.

Table 2. Comparison of Cellular Effects Induced by $\mathrm{Nano}-\mathrm{Mg}(\mathrm{OH})_{2} / \mathrm{Cr}(\mathrm{VI})$ and Free $\mathrm{Cr}(\mathrm{VI})^{a}$

\begin{tabular}{|c|c|c|c|c|c|c|}
\hline \multirow[b]{2}{*}{ comparison item } & \multicolumn{3}{|c|}{ HEK293 } & \multicolumn{3}{|c|}{ HepG2 } \\
\hline & nano- $\mathrm{Mg}(\mathrm{OH})_{2} / \mathrm{Cr}(\mathrm{VI})$ & free $\mathrm{Cr}(\mathrm{VI})$ & remediation (\%) & nano- $\mathrm{Mg}(\mathrm{OH})_{2} / \mathrm{Cr}(\mathrm{VI})$ & free $\mathrm{Cr}(\mathrm{VI})$ & remediation (\%) \\
\hline free $\mathrm{Cr}(\mathrm{VI})$ in solution & $35 \%$ & $100 \%$ & $65 \%$ & $35 \%$ & $100 \%$ & $65 \%$ \\
\hline cellular uptake of $\mathrm{Cr}(\mathrm{VI})$ & $3.5 \mathrm{pg} / \mathrm{cell}$ & $7.4 \mathrm{pg} /$ cell & $53 \%$ & $2.2 \mathrm{pg} / \mathrm{cell}$ & $4.4 \mathrm{pg} /$ cell & $50.0 \%$ \\
\hline ROS & 1.2 & 1.8 & $33 \%$ & 1.1 & 2.0 & $45 \%$ \\
\hline apoptosis & $7.4 \%$ & $11.5 \%$ & $36 \%$ & $7.8 \%$ & $12.8 \%$ & $39 \%$ \\
\hline cell viability & $66 \%$ & $26 \%$ & $40 \%$ & $61 \%$ & $28 \%$ & $33 \%$ \\
\hline
\end{tabular}

${ }^{a}$ Cell assays were carried out using $10.5 \mu \mathrm{M} \mathrm{Cr}(\mathrm{VI})$ or equivalent amount of Nano- $\mathrm{Mg}(\mathrm{OH})_{2}$ and its adduct. Incubation time is $24 \mathrm{~h}$. 


\section{Notes}

The authors declare no competing financial interest.

\section{ACKNOWLEDGMENTS}

This work was supported by the National Basic Research Program of China (2010CB933504) and National Natural Science Foundation of China (21077068 and 21137002).

\section{REFERENCES}

(1) Su, Y.; Yan, X.; Pu, Y.; Xiao, F.; Wang, D.; Yang, M. Risks of Single-Walled Carbon Nanotubes Acting as Contaminants-Carriers: Potential Release of Phenanthrene in Japanese Medaka (Oryzias latipes). Environ. Sci. Technol. 2013, 47 (9), 4704-4710.

(2) Watanabe, N. Decreased number of sperms and Sertoli cells in mature rats exposed to diesel exhaust as fetuses. Toxicol. Lett. 2005, $155(1), 51-58$

(3) Cao, C.-Y.; Qu, J.; Wei, F.; Liu, H.; Song, W.-G. Superb adsorption capacity and mechanism of flowerlike magnesium oxide nanostructures for lead and cadmium ions. ACS Appl. Mater. Interfaces 2012, 4 (8), 4283-4287.

(4) Liu, W.; Huang, F.; Liao, Y.; Zhang, J.; Ren, G.; Zhuang, Z.; Zhen, J.; Lin, Z.; Wang, C. Treatment of CrVI-Containing $\mathrm{Mg}(\mathrm{OH})_{2}$ Nanowaste. Angew. Chem., Int. Ed. 2008, 47 (30), 5619-5622.

(5) Debasis, B.; Manashi, B.; Stohs, S. J. Chromium (VI)-induced oxidative stress, apoptotic cell death and modulation of p53 tumor suppressor gene. Mol. Cell. Biochem. 2001, 222, 149-158.

(6) Lynne, P. National Pollutant Release Inventory National Overview 1998. Canadian Environmental Protection Act; 1998.

(7) Chromium Nickel Welding IARC monographs on the evaluation of carcinogenic risks to humans; International Agency for Research on Cancer, 1989, Vol. 49.

(8) Patlolla, A. K.; Barnes, C.; Hackett, D.; Tchounwou, P. B. Potassium dichromate induced cytotoxicity, genotoxicity and oxidative stress in human liver carcinoma (HepG2) cells. Int. J. Environ. Res. Public Health 2009, 6 (2), 643-653.

(9) Tsapakos, M. J.; Hampton, T. H.; Wetterhahn, K. E. Chromium (VI)-induced DNA lesions and chromium distribution in rat kidney, liver, and lung. Cancer Res. 1983, 43 (12 Part 1), 5662-5667.

(10) Moon, D.; Wazne, M.; Dermatas, D.; Christodoulatos, C.; Sanchez, A.; Grubb, D.; Chrysochoou, M.; Kim, M. Long-term treatment issues with chromite ore processing residue (COPR): $\mathrm{Cr}^{6+}$ reduction and heave. J. Hazardous Mater. 2007, 143 (3), 629-635.

(11) Nickens, K. P.; Patierno, S. R.; Ceryak, S. Chromium genotoxicity: A double-edged sword. Chem.-Biol. Interact. 2010, 188 (2), 276-288

(12) Rengaraj, S.; Joo, C. K.; Kim, Y.; Yi, J. Kinetics of removal of chromium from water and electronic process wastewater by ion exchange resins: $1200 \mathrm{H}, 1500 \mathrm{H}$ and IRN97H. J. Hazardous Mater. 2003, 102 (2), 257-275.

(13) Qin, G.; McGuire, M. J.; Blute, N. K.; Seidel, C.; Fong, L. Hexavalent chromium removal by reduction with ferrous sulfate, coagulation, and filtration: A pilot-scale study. Environ. Sci. Technol. 2005, 39 (16), 6321-6327.

(14) Galán, B.; Castañeda, D.; Ortiz, I. Removal and recovery of $\mathrm{Cr}$ (VI) from polluted ground waters: A comparative study of ionexchange technologies. Water res. 2005, 39 (18), 4317-4324.

(15) Cheng, Y.; Yan, F.; Huang, F.; Chu, W.; Pan, D.; Chen, Z.; Zheng, J.; Yu, M.; Lin, Z.; Wu, Z. Bioremediation of Cr (VI) and immobilization as $\mathrm{Cr}$ (III) by Ochrobactrum anthropi. Environ. Sci. Technol. 2010, 44 (16), 6357-6363.

(16) Liu, W.; Huang, F.; Liao, Y.; Zhang, J.; Ren, G.; Zhuang, Z.; Zhen, J.; Lin, Z.; Wang, C. Treatment of $\mathrm{Cr}(\mathrm{VI})$-Containing $\mathrm{Mg}(\mathrm{OH})_{2}$ Nanowaste. Angew. Chem., Int. Ed. 2008, 47 (30), 56195622 .

(17) Mu, Q.; Su, G.; Li, L.; Gilbertson, B. O.; Yu, L. H.; Zhang, Q.; Sun, Y.-P.; Yan, B. Size-dependent cell uptake of protein-coated graphene oxide nanosheets. ACS Appl. Mater. Interfaces 2012, 4 (4), $2259-2266$
(18) Zhang, Y.; Tekobo, S.; Tu, Y.; Zhou, Q.; Jin, X.; Dergunov, S. A.; Pinkhassik, E.; Yan, B. Permission to Enter Cell by Shape: Nanodisk vs Nanosphere. ACS Appl. Mater. Interfaces 2012, 4 (8), 4099-4105.

(19) Ecker, M. Purification of liquids, especially water containing heavy metal ions, involves bonding the impurities on or in magnesium hydroxide. DE Patent 10,318,746, 2004.

(20) Kent, J. A. Riegel's Handbook of Industrial Chemistry; Springer: New York, 2003; pp 429-430.

(21) Cheremisinoff, N. P. Handbook of Solid Waste Management and Waste Minimization Technologies; Elsevier: Burlington, 2003; pp 192193.

(22) Edgington, A. J.; Roberts, A. P.; Taylor, L. M.; Alloy, M. M.; Reppert, J.; Rao, A. M.; Mao, J.; Klaine, S. J. The influence of natural organic matter on the toxicity of multiwalled carbon nanotubes. Environ. Toxicol. Chem. 2010, 29 (11), 2511-2518.

(23) Zhu, X.; Zhou, J.; Cai, $\mathrm{Z} . \mathrm{TiO}_{2}$ nanoparticles in the marine environment: Impact on the toxicity of tributyltin to abalone (Haliotis diversicolor supertexta) embryos. Environ. Sci. Technol. 2011, 45 (8), 3753-3758.

(24) Hu, J.; Wang, D.; Forthaus, B. E.; Wang, J. Quantifying the effect of nanoparticles on As (V) ecotoxicity exemplified by nano$\mathrm{Fe}_{2} \mathrm{O}_{3}$ (magnetic) and nano- $\mathrm{Al}_{2} \mathrm{O}_{3}$. Environ. Toxicol. Chem. 2012, 31 (12), 2870-2876.

(25) Wang, D.; Hu, J.; Forthaus, B. E.; Wang, J. Synergistic toxic effect of nano- $\mathrm{Al}_{2} \mathrm{O}_{3}$ and $\mathrm{As}(\mathrm{V})$ on Ceriodaphnia dubia. Environ. Pollut. 2011, 159 (10), 3003-3008.

(26) Fan, W.; Cui, M.; Liu, H.; Wang, C.; Shi, Z.; Tan, C.; Yang, X. Nano- $\mathrm{TiO}_{2}$ enhances the toxicity of copper in natural water to Daphnia magna. Environ. Pollut. 2011, 159 (3), 729-734.

(27) Zhang, X.; Sun, H.; Zhang, Z.; Niu, Q.; Chen, Y.; Crittenden, J. C. Enhanced bioaccumulation of cadmium in carp in the presence of titanium dioxide nanoparticles. Chemosphere 2007, 67 (1), 160-166.

(28) Hu, J.; Wang, D.; Wang, J.; Wang, J. Toxicity of lead on Ceriodaphnia dubia in the presence of nano- $\mathrm{CeO}_{2}$ and nano- $\mathrm{TiO}_{2}$. Chemosphere 2012, 89 (5), 536-541.

(29) Pan, X.; Wang, Y.; Chen, Z.; Pan, D.; Cheng, Y.; Liu, Z.; Lin, Z.; Guan, $\mathrm{X}$. Investigation of Antibacterial Activity and Related Mechanism of a Series of Nano-Mg $(\mathrm{OH})_{2}$. ACS Appl. Mater. Interfaces 2013, 5 (3), 1137-1142.

(30) Jahnen-Dechent, W.; Ketteler, M. Magnesium basics. Clin. Kidney J. 2012, 5 (Suppl 1), i3-i14.

(31) Waluyo, I.; Huang, C.; Nordlund, D.; Bergmann, U.; Weiss, T. M.; Pettersson, L. G.; Nilsson, A. The structure of water in the hydration shell of cations from x-ray Raman and small angle x-ray scattering measurements. J. Chem. Phys. 2011, 134, No. 064513.

(32) Cedervall, T.; Lynch, I.; Foy, M.; Berggård, T.; Donnelly, S. C.; Cagney, G.; Linse, S.; Dawson, K. A. Detailed identification of plasma proteins adsorbed on copolymer nanoparticles. Angew. Chem., Int. Ed. 2007, 46 (30), 5754-5756.

(33) Cedervall, T.; Lynch, I.; Lindman, S.; Berggård, T.; Thulin, E.; Nilsson, H.; Dawson, K. A.; Linse, S. Understanding the nanoparticleprotein corona using methods to quantify exchange rates and affinities of proteins for nanoparticles. Proc. Natl. Acad. Sci. 2007, 104 (7), 2050-2055.

(34) Gebauer, J. S.; Malissek, M.; Simon, S.; Knauer, S. K.; Maskos, M.; Stauber, R. H.; Peukert, W.; Treuel, L. Impact of the nanoparticle-protein corona on colloidal stability and protein structure. Langmuir 2012, 28 (25), 9673-9679.

(35) Harush-Frenkel, O.; Altschuler, Y.; Benita, S. Nanoparticle-cell interactions: drug delivery implications. Crit. Rev. Ther. Drug Carrier Syst. 2008, 25 (6), 485-544.

(36) $\mathrm{Mu}$, Q.; Broughton, D. L.; Yan, B. Endosomal leakage and nuclear translocation of multiwalled carbon nanotubes: developing a model for cell uptake. Nano Lett. 2009, 9 (12), 4370-4375.

(37) Dausend, J.; Musyanovych, A.; Dass, M.; Walther, P.; Schrezenmeier, H.; Landfester, K.; Mailänder, V. Uptake mechanism of oppositely charged fluorescent nanoparticles in HeLa cells. Macromol. Biosci. 2008, 8 (12), 1135-1143. 
(38) Su, G.; Zhou, H.; Mu, Q.; Zhang, Y.; Li, L.; Jiao, P.; Jiang, G.; Yan, B. Effective Surface Charge Density Determines the Electrostatic Attraction between Nanoparticles and Cells. J. Phys. Chem. C 2012, 116 (8), 4993-4998.

(39) Ottenwaelder, H.; Wiegand, H.; Bolt, H. Uptake of Cr (VI) by human erythrocytes: Evidence for a carrier-mediated transport mechanism. Sci. Total Environ. 1988, 71 (3), 561-566.

(40) Wiegand, H.; Ottenwälder, H.; Bolt, H. Fast uptake kinetics in vitro of $\mathrm{Cr}$ (VI) by red blood cells of man and rat. Arch. Toxicol. 1985, 57 (1), 31-34.

(41) Alexander, J.; Aaseth, J. Uptake of chromate in human red blood cells and isolated rat liver cells: the role of the anion carrier. Analyst 1995, 120 (3), 931-933.

(42) Cabantchik, Z.; Rothstein, A. Membrane proteins related to anion permeability of human red blood cells. J. Membr. Biol. 1974, 15 (1), 207-226.

(43) Wetterhahn, K. E.; Hamilton, J. W.; Aiyar, J.; Borges, K. M.; Floyd, R. Mechanism of chromium (VI) carcinogenesis. Biol. Trace Element Res. 1989, 21 (1), 405-411.

(44) Aiyar, J.; Berkovits, H. J.; Floyd, R. A.; Wetterhahn, K. E. Reaction of chromium (VI) with glutathione or with hydrogen peroxide: identification of reactive intermediates and their role in chromium (VI)-induced DNA damage. Environ. Health Persp. 1991, 92, 53.

(45) Poljsak, B.; Pócsi, I.; Pesti, M. Interference of chromium with cellular functions. In Cellular Effects of Heavy Metals; Springer: 2011; pp 59-86.

(46) Novo, E.; Parola, M. Redox mechanisms in hepatic chronic wound healing and fibrogenesis. Fibrogenesis \& Tissue Repair 2008, 1 (1), 5 .

(47) Zhitkovich, A. Importance of chromium-DNA adducts in mutagenicity and toxicity of chromium (VI). Chem. Res. Toxicol. 2005, 18 (1), 3-11.

(48) Macfie, A.; Hagan, E.; Zhitkovich, A. Mechanism of DNAProtein Cross-Linking by Chromium. Chem. Res. Toxicol. 2009, 23 (2), 341-347.

(49) Pritchard, D. E.; Ceryak, S.; Ha, L.; Fornsaglio, J. L.; Hartman, S. K.; O’Brien, T. J.; Patierno, S. R. Mechanism of apoptosis and determination of cellular fate in chromium (VI)-exposed populations of telomerase-immortalized human fibroblasts. Cell Growth \& Differentiation: Molec. Biol. J. Am. Assoc. Cancer Res. 2001, 12 (10), 487-496.

(50) Wang, X.-F.; Xing, M.-L.; Shen, Y.; Zhu, X.; Xu, L.-H. Oral administration of $\mathrm{Cr}$ (VI) induced oxidative stress, DNA damage and apoptotic cell death in mice. Toxicology 2006, 228 (1), 16-23.

(51) Vasylkiv, O. Y.; Kubrak, O. I.; Storey, K. B.; Lushchak, V. I. Cytotoxicity of chromium ions may be connected with induction of oxidative stress. Chemosphere 2010, 80 (9), 1044-1049.

(52) . Bagchi, D.; Bagchi, M.; Stohs, S. J. Chromium (VI)-induced oxidative stress, apoptotic cell death and modulation of p53 tumor suppressor gene. In Molecular Mechanisms of Metal Toxicity and Carcinogenesis; Springer, 2001; pp 149-158.

(53) Gavin, I. M.; Gillis, B.; Arbieva, Z.; Prabhakar, B. S. Identification of human cell responses to hexavalent chromium. Environ. Molec. Mutagen. 2007, 48 (8), 650-657.

(54) Ye, J.; Wang, S.; Leonard, S. S.; Sun, Y.; Butterworth, L.; Antonini, J.; Ding, M.; Rojanasakul, Y.; Vallyathan, V.; Castranova, V. Role of reactive oxygen species and p53 in chromium (VI)-induced apoptosis. J. Biol. Chem. 1999, 274 (49), 34974-34980. 